\title{
Space partitioning among damselfishes in the Caribbean coast of Panama: the role of habitat preferences
}

\author{
Laís de Carvalho Teixeira Chaves ${ }^{1}$, Carlos Gustavo A. Ormond², Elizabeth S. McGinty \\ and Beatrice Padovani Ferreira ${ }^{1}$
}

This study aimed to assess abundance and habitat use by juvenile and adult damselfishes, as much as the benthic cover of different reefs on Isla Colon, Bocas del Toro, Panama. Reefs were selected considering different levels of wave exposure and depths. Damselfish and benthic communities were distinct between reefs. The most abundant species in the sheltered deeper reef was Stegastes planifrons followed by S. leucostictus, and they were also recorded in the sheltered shallower reef. Low densities of S. partitus and S. variabilis were also observed in the sheltered deeper reef, as these species are apparently restricted to higher depths. Additionally, these reefs presented patches with high cover of live and dead massive coral. Shallow depths presented high abundances of S. adustus, indicating a preference of this species for shallow habitats and exhibiting a two-fold increase in abundance at higher wave surge. Also, Microspathodon chrysurus reached higher numbers in shallow depths. Furthermore, the exposed reef presented a high cover (\%) of algae groups and the firecoral Millepora alcicornis, acknowledged as a preferred habitat for $M$. chrysurus and other reef fish. In this study, distinct habitat uses were observed, with patterns regulated by depth and/or wave exposure levels and/or availability of specific benthic cover. For site-attached species as damselfish, habitat specialization, competition and/or non-random recruitment patterns have been found to rule distributional patterns. Similar results for damselfish relative abundances were found compared to studies conducted within Panama and other reefs throughout the Caribbean region over three decades ago, indicating strong habitat affinity for the most abundant species. However, severe reductions of habitat availability following coral mass-mortality events may have disrupted their distributional patterns.

Este estudo teve como objetivo avaliar a abundância e uso do habitat por juvenis e adultos de peixes-donzela, assim como as comunidades bentônicas em distintos recifes de Isla Colon, Bocas del Toro, Panamá. Os recifes foram escolhidos considerando diferentes níveis de exposição a ondas e profundidade. As comunidades de peixes e bentos estudadas se mostraram distintas. A espécie mais abundante em recifes com maior profundidade e abrigados foi Stegastes planifrons, seguida por S. leucostictus, que também foram observadas em recifes rasos abrigados. As baixas abundâncias de S. partitus e S. variabilis também foram observadas no primeiro recife citado e estas espécies foram aparentemente restritas à profundidade maiores. Adicionalmente, estes mesmos recifes apresentaram uma vasta cobertura de corais massivos, vivos ou mortos. Stegastes adustus apresentou sua maior abundância em baixas profundidades, indicando uma preferência por habitats rasos, aumentando em duas vezes com a exposição a ondas. Os recifes rasos também tiveram maior abundância de Microspathodon chrysurus. Além disso, o recife com maior exposição apresentou extenso percentual de cobertura por algas e o coral-de-fogo Millepora alcicornis, reconhecido habitat preferencial de $M$. chrysurus e outras espécies de peixes. Neste trabalho, diferentes padrões de uso do habitat foram encontrados, sendo regulados pela profundidade e/ou exposição e ainda a disponibilidade de determinada cobertura bentônica. Para espécies fortemente associadas ao substrato, a especialização, a competição e padrões não aleatórios do recrutamento são conhecidos determinantes dos padrões distribucionais. Este estudo apresentou resultados similares a outros conduzidos há 30 anos no Panamá e outros recifes do Caribe, indicando que as espécies mais abundantes mantêm forte afinidade com o habitat. Entretanto, severas reduções na disponibilidade de habitat, seguidas de eventos de mortalidade em massa, podem ter possivelmente afetado seus padrões de distribuição.

Key words: Bocas del Toro, Coral reefs, Pomacentrid, Reef fish, Territorial herbivores.

\footnotetext{
${ }^{1}$ Universidade Federal de Pernambuco, Departamento de Oceanografia. Av. Arquitetura s/n. Cidade Universitária. 50670-901 Recife, PE, Brazil. chaveslais@yahoo.com.br (LCTC); beatrice@ufpe.br (BPF)

${ }^{2}$ Simon Fraser University, British Columbia, Vancouver, Canada V5A 1S6. cormond@sfu.ca

${ }^{3}$ University of Texas at Arlington, Arlington, TX 76019 USA. mcginty@uta.edu
} 


\section{Introduction}

Coral reefs are among the most productive systems in the marine environment (Spalding et al., 2001). These systems are changing worldwide in the last decades, due to climate changes, hurricanes, diseases, overfishing, and eutrophication (Hughes et al., 2003; Pandolfi et al., 2005). Such disturbances have often resulted in ecological phase shifts, from coral- to macroalgal-dominated reefs (McCook, 1999; Scheffer et al., 2001), which may be observed on many Caribbean reefs (Hughes, 1994; McClanahan et al., 2002) and other regions worldwide (Hughes et al., 2007).

Coral cover declined by nearly $80 \%$ in the Caribbean in the late 1970s and 1980s (Gardner et al., 2003), with decreases as high as $50-70 \%$ recorded in several areas along the coast of Panama (Guzman, 2003). Massive coral loss, in turn, has caused declines in structural complexity, leading to negative consequences to the entire reef community (Alvarez-Filip et al., 2009). Especially when species strongly dependent upon the cover, diversity and complexity of their respective habitat are usually more jeopardized by these natural and/or anthropogenic disturbances (Jones \& Syms, 1998; Jones et al., 2004; Graham et al., 2006).

Herbivorous reef fish play major roles in reef resilience, as they control abundance and distribution of macroalgae (Szmant, 2001; Hughes et al., 2007). Territorial herbivores such damselfishes (family Pomacentridae) are capable of modifying algal communities in different ways (Hata \& Kato, 2003, 2004; Ceccarelli et al., 2005; Jones et al., 2006), such as enhancing the net primary production (Klumpp et al., 1987; Ferreira et al., 1998). Indirectly, territorial herbivores exert significant effects on the foraging activity of roving herbivores through their aggressive territorial defense (Hixon \& Beets, 1993), and through "weeding” behavior distress coral recruitment, survival, and diversity (Gleason, 1996; Gochfeld, 2010). Overall, these species are considered keystone species in reef systems (Hixon \& Brostoff, 1983).

As widely distributed and abundant on reef systems worldwide (Doherty, 1983; Meekan et al., 1995; Ceccarelli et al., 2001), damselfishes occupy up to $90 \%$ of some reef areas (Ceccarelli, 2005; Ilarri et al., 2008; Medeiros et al., 2007, 2010). Thus, by their abundance, behavior and directly use of turf algae, the main bulk of primary production on coral reef systems, they can be relevant actors on phase shifts from coral- to algae-dominated reefs (Ceccarelli et al., 2011). Distribution patterns found for this particular group of species, however, are highly variable at several spatial scales (e.g. microhabitats, depth, exposure, reef zones, systems) (Williams, 1982; Meekan et al., 1995; Holbrook et al., 2000; Medeiros et al., 2010). Although pre-recruitment processes are important driving forces in adult abundance and distribution (Doherty, 1983), post-settlement processes such as presence of preferred microhabitats (Holbrook et al., 2000), predator abundance (Hixon \& Beets, 1993), intra- and interspecific competition (Sweatman, 1985; Tolimieri, 1998; Bay et al., 2001) are as much as important. Nevertheless, different key mechanisms can be acting synergistically for each species.

This group has been studied throughout the Caribbean, with data available for habitat use, recruitment, behavior, diet and, age and growth of some species (Robertson, 1984, 1996; Gutierrez, 1998; Holbrook et al., 2000; Wilson \& Meekan, 2002). However, most of these studies to date focused separately on a single or few species, thus not providing more comprehensive data on damselfish community and their association with environmental descriptors. This study aimed to determine abundance and space use of damselfishes across a coastal island of Panama, as well as their relationship with environmental factors such as depth, wave exposure and benthic cover using a more quantitative approach.

\section{Material and Methods}

\section{Study area}

The present research was conducted in Bocas del Toro archipelago, Isla Colón, Panama. The whole archipelago comprises an area of $c a$. 3,500 km², formed by six large forested islands and hundreds of small mangrove cays (Guzmán, 2003). Surrounding all these islands and along a large part of the mainland coast, there are fringing coral reefs up to $20 \mathrm{~m}$ deep and dozens of shallow reef patches. The whole area represents the second most important contributor on reef formations in the Caribbean coast of Panama with approximately $87 \mathrm{~km}^{2}$ of fringing reefs (Guszmán, 2003). The reefs of the archipelago have been evaluated in the past decade and live coral cover up to $50 \%$ has been reported, depending on the depth, reaching up to 90\% in shallow areas (Guzmán \& Guevara, 1998a, 1998b, 1999, 2001). Nevertheless, declines on coral cover throughout this area have also been observed in the last decade (Guzmán, 2003).

Three distinct reefs were chosen for this study (Fig.1). Pete's Reef (PT) is a shallow lagoon with patch reefs near mangrove mud flats $(\sim 1 \mathrm{~m})$. Water motion is low and benthic communities are dominated by numerous species of sponges and the fingercoral Porites porites (Pallas, 1766). Conch Point (CO) is a wave-protected near-shore fringing reef lined with mangroves (Rhizophora mangle L.). Depths range from 0.5 to $1 \mathrm{~m}$ at the mangrove edge and increase to approximately seven $\mathrm{m}$ at a $20 \mathrm{~m}$ distance from shore. The substratum immediately adjacent to the mangrove edge is covered with turtle grass Thalassia testudinum Koenig and green algae, while deeper areas are characterized by the presence of patch reefs and sponges. Shallower $(\sim 0.50 \mathrm{~m})$ and relatively more exposed, Lime Point (LM) has a much longer fetch reaching the open waters of the Caribbean; lacking mangroves and characterized by patches of T. testudinum and Syringodium filiforme Kuetzing (manatee grass), as well as sand alongside its extension. Within this reef, sites closer to the reef edge, and deeper ( $1 \mathrm{~m}$ ) ones showed higher coverage of live coral. On PT and LM observations were done through snorkeling, whereas SCUBA was used in CO. 


\section{Surveys}

The abundance and distribution of territorial damselfishes and benthic community were assessed in December 2010 and January 2011. Abundance of juveniles and adult damselfishes, as well as habitat use, were assessed using visual census for fish density and percent benthic cover over transects of $10 \mathrm{x}$ $2 \mathrm{~m}(\mathrm{PT}=20 ; \mathrm{CO}=20$, and $\mathrm{LM}=16 ; \mathrm{N}=56)$. The studied damselfish species are easily distinguishable underwater based on their coloration, both as juveniles and adults. To minimize edge effect, records included damselfishes with at least $50 \%$ of its territory inside the transect boundaries.

Depth measures were taken for each transect. Benthic cover was estimated using the linear point-intercept method adapted from Liddell et al. (1984). At each $50 \mathrm{~cm}$ interval, substratum was recorded according to the following categories: (1) articulated calcareous algae (algae that project $<5 \mathrm{~cm}$ above the substratum, mainly branched calcareous forms), (2) macroalgae (algae that project $>5 \mathrm{~cm}$ above the substratum, mainly fleshy algae), (3) encrusting coralline algae, (4) filamentous algae, (5) branching corals (mainly Millepora spp. and Porites spp.), (6) massive corals (Siderastraea spp., Montastraea spp., Diploria spp., Porites spp.), (7) massive dead corals (overgrown by algae), (8) zoanthids, (9) sea urchins, (10) sponges, (11) sand, (12) rubble (pieces of broken corals), and (13) mud.

\section{Statistical analysis}

One-way Analysis of Variance (ANOVA) was used to test differences between species abundance at both life stages (juvenile and adult) and benthic percent cover among reefs. When necessary, data was $\log 10(x+1)$ transformed, and the Student-Newman-Keuls a posteriori test was used. The structure of damselfish assemblages (i.e., relative abundance of the different species and life stages) was analyzed using non-Metric Multidimensional Scaling Analysis (MDS), which was later tested for significance of groups formed for exposure and depth factors by the Analysis of similarity (oneway ANOSIM). Separate One-way ANOSIM for these factors was also used to test differences between benthic communities (Clarke \& Gorley, 2001). Species' life stages and benthic community relationship was obtained, using the canonical correspondence analysis (CCA) ordination. Significant environmental parameters were selected with the Monte Carlo permutation test. Data were log-transformed and the CANOCO for Windows 4.5 software was used (ter Braak, 1995).

\section{Results}

\section{Damselfish distribution among reefs}

Fifty-six visual censuses yielded sightings of 1,178 damselfishes belonging to six common Caribbean species: the dusky damselfish Stegastes adustus (Troschel 1865), the threespot damselfish S. planifrons (Cuvier, 1830), the beaugregory S. leucostictus (Müller \& Troschel, 1848), the bicolor damselfish S. partitus (Poey, 1868), the cocoa damselfish S. variabilis (Castelnau, 1855), and the yellowtail damselfish Microspathodon chrysurus (Cuvier, 1830) (Table 1 ). The former two species represented the majority of overall abundance, including adults and juveniles ( 90\%). Stegastes adustus was especially abundant in shallow reefs (PT and LM) (Fig. 2). The abundance of both juveniles and adults from this species were very similar in Pete's Reef, but adult abundance was significantly different between this site and Lime Point (ANOVA; $p<0.0001$ ) - on the latter it was observed a two-fold increase with wave (Fig. 2). Stegastes planifrons presented closer affinity to sheltered reefs (PT and CO), with a significant three-fold increase (ANOVA; $\mathrm{p}<0.0001$ ) in shallow waters (PT). On the exposed reef (LM) juveniles presented very low abundances and adults were absent. The beaugregory $S$. leucostictus was not very abundant when compared with other species, but were observed only in sheltered reefs (PT and CO). Adults from this species were restricted to deeper patch reefs (CO), whereas juveniles did not differed in abundance between depths. Juveniles and adults of $S$. variabilis and $S$. partitus presented very low abundances and were restricted to deeper patches (CO). The yellowtail damselfish $M$. chrysurus was recorded both in the shallow and exposed (LM) and the deeper and sheltered reef (CO), showing no constraint concerning depth or exposure. Adults and juveniles, however, significantly increased $3 \mathrm{x}$ and $8 \mathrm{x}$, respectively at LM (ANOVA; $\mathrm{p}=0.0037$ and $\mathrm{p}=0.0002$, respectively) together with the abundance of adult $S$. adustus (Table 1; Fig. 2), indicating preference for exposed reefs.

Non-metric multidimensional scaling analysis presented in Fig. 3 (a-b) showed distinct groups for damselfish communities, which were separated between wave exposure and depth. The low stress value indicated that the observed sample distribution in the two dimensional space provided a reliable interpretation of the differences among damselfish community structure at the study sites. Separated one-way ANOSIM corroborated the formation of these groups, with low degree of overlap between exposure (global $\mathrm{R}=0.654$, $\mathrm{p}=0.001)$ and depth (global $\mathrm{R}=0.589, \mathrm{p}=0.001)$.

\section{Benthic communities}

Benthic communities also contributed for differences found among reefs. However, one-way ANOSIM tests detected significant differences among reefs regarding exposure $(\mathrm{R}=0.655 ; \mathrm{p}=0.001)$, but not for benthic cover $(\mathrm{R}=0.092 ; \mathrm{p}=0.055)$.

Pete's Reef (PT) and Conch Point (CO), both being sheltered reefs, presented higher cover of live or dead corals, including massive corals (mainly brain corals) and the branching finger coral Porites spp. (Table 1). Coral cover was always higher on the shallower reef (PT). Particularly, the deeper reef (CO) presented higher cover of sponges and sand, the latter being a consequence of more dispersed patch reefs. The exposed reef (LM) was an algae-dominated reef, comprising crustose, articulated and macroalgae. Also, colonies of the firecoral Millepora alcicornis Linnaeus, 1758, zoanthids and rubble were commonly observed. 
Table 1. Species abundance by life stage and percent composition of substrata (Mean \pm SE), plus ANOVA results and StudentNewman-Keuls (SNK) comparison between reefs. ns = non-significant; ${ }^{*} \mathrm{p}<0.05 ;{ }^{* *} \mathrm{p}<0.01 ;{ }^{* * *} \mathrm{p}<0.001$.

\begin{tabular}{|c|c|c|c|c|c|c|}
\hline & PETE'S REEF & CONCH POINT & LIME POINT & $\mathrm{p}$ & $\mathrm{F}$ & SNK \\
\hline \multicolumn{7}{|l|}{ JUVENILES } \\
\hline S.planifrons & $4.05 \pm 0.63$ & $4.75 \pm 1.01$ & $0.12 \pm 0.08$ & $* * *$ & 10.36 & $\mathrm{PT}=\mathrm{CO}>\mathrm{LM}$ \\
\hline S.adustus & $5.75 \pm 0.89$ & 0 & $4.00 \pm 0.83$ & $* * *$ & 19.38 & $\mathrm{PT}=\mathrm{LM}>\mathrm{CO}$ \\
\hline S.leucostictus & $0.20 \pm 0.11$ & $0.10 \pm 0.06$ & 0 & $* * *$ & 9.73 & $\mathrm{PT}=\mathrm{CO}>\mathrm{LM}$ \\
\hline S.variabilis & 0 & $0.10 \pm 0.07$ & 0 & ns & 1.89 & - \\
\hline S.partitus & 0 & $0.25 \pm 0.16$ & 0 & ns & 2.18 & - \\
\hline M.chrysurus & 0 & $0.20 \pm 0.15$ & $1.62 \pm 0.50$ & $* * *$ & 10.07 & $\mathrm{LM}>\mathrm{CO}>\mathrm{PT}$ \\
\hline \multicolumn{7}{|l|}{ ADULTS } \\
\hline S.planifrons & $12.40 \pm 1.56$ & $4.55 \pm 0.72$ & 0 & $* * *$ & 33.59 & $\mathrm{PT}>\mathrm{CO}>\mathrm{LM}$ \\
\hline S.adustus & $4.40 \pm 0.78$ & $0.05 \pm 0.05$ & $17.81 \pm 1.11$ & $* * *$ & 147.69 & $\mathrm{LM}>\mathrm{PT}>\mathrm{CO}$ \\
\hline S.leucostictus & 0 & $1.75 \pm 0.48$ & 0 & ns & 1.89 & - \\
\hline S.variabilis & 0 & $0.05 \pm 0.05$ & 0 & ns & 0.98 & - \\
\hline S.partitus & 0 & $0.45 \pm 0.18$ & 0 & $* *$ & 5.32 & $\mathrm{CO}>\mathrm{PT}=\mathrm{LM}$ \\
\hline M.chrysurus & 0 & $0.20 \pm 0.15$ & $0.75 \pm 0.23$ & $* *$ & 6.24 & $\mathrm{LM}>\mathrm{CO}>\mathrm{PT}$ \\
\hline \multicolumn{7}{|l|}{ CORAL } \\
\hline Dead & $26.90 \pm 2.68$ & $15.48 \pm 2.39$ & $0.60 \pm 0.41$ & $* * *$ & 32.98 & $\mathrm{PT}>\mathrm{CO}>\mathrm{LM}$ \\
\hline Massive & $43.81 \pm 5.46$ & $29.52 \pm 2.78$ & $12.80 \pm 3.03$ & $* * *$ & 13.77 & $\mathrm{PT}>\mathrm{CO}>\mathrm{LM}$ \\
\hline Branching & $7.86 \pm 2.32$ & 0 & $7.74 \pm 2.57$ & $* *$ & 5.71 & $\mathrm{PT}=\mathrm{LM}>\mathrm{CO}$ \\
\hline \multicolumn{7}{|l|}{ ALGAE } \\
\hline Turf matrix & $0.95 \pm 0.56$ & $0.24 \pm 0.24$ & $37.80 \pm 3.95$ & $* *$ & 108.1 & $\mathrm{LM}>\mathrm{PT}=\mathrm{CO}$ \\
\hline Macroalgae & $0.24 \pm 0.24$ & 0 & $10.12 \pm 2.98$ & $* * *$ & 14.11 & $\mathrm{LM}>\mathrm{PT}=\mathrm{CO}$ \\
\hline Crustose & 0 & $0.24 \pm 0.24$ & $7.74 \pm 1.68$ & $* * *$ & 25.28 & $\mathrm{LM}>\mathrm{PT}=\mathrm{CO}$ \\
\hline Filamentous & $8.33 \pm 4.09$ & $12.86 \pm 1.96$ & $13.10 \pm 2.52$ & ns & 0.78 & - \\
\hline \multicolumn{7}{|l|}{ OTHER } \\
\hline Zoantids & $0.95 \pm 0.56$ & $0.24 \pm 0.24$ & $6.25 \pm 2.60$ & $* *$ & 5.58 & $\mathrm{LM}>\mathrm{PT}=\mathrm{CO}$ \\
\hline Sponges & $6.19 \pm 1.04$ & $12.62 \pm 1.63$ & $0.30 \pm 0.30$ & $* * *$ & 24.98 & $\mathrm{CO}>\mathrm{PT}>\mathrm{LM}$ \\
\hline Urchins & $1.90 \pm 1.44$ & 0 & 0 & ns & 1.56 & - \\
\hline Sand & $2.62 \pm 0.94$ & $23.57 \pm 4.07$ & $0.30 \pm 0.30$ & $* * *$ & 24.99 & $\mathrm{CO}>\mathrm{PT}=\mathrm{LM}$ \\
\hline Rubble & $0.24 \pm 0.24$ & $1.19 \pm 0.59$ & $3.27 \pm 1.28$ & * & 4.06 & $\mathrm{LM}>\mathrm{PT}=\mathrm{CO}$ \\
\hline Mud & 0 & $4.05 \pm 2.92$ & 0 & ns & 1.72 & - \\
\hline Depth & $1.15 \pm 0.02$ & $8.15 \pm 0.08$ & $1.34 \pm 0.04$ & $* *$ & 1.36 & $\mathrm{CO}>\mathrm{PT}=\mathrm{LM}$ \\
\hline
\end{tabular}

\section{Fish-habitat relationships}

Habitat relationships for damselfish and benthic descriptors using the canonical correspondence analysis are presented on Fig. 4a-b. The first two axes were significant ( $\mathrm{p}=0.001$ ) and accounted for $61.4 \%$ and $21.6 \%$, respectively, of the relationship between species and explanatory variables. The first axis, responsible for most of explained variation, was positively related to habitats that presented high cover of branching corals, macroalgae and articulated calcareous algae (Fig. 4a). Such descriptors represented samples of Lime Point (shallow and exposed), which $S$. adustus and $M$. chrysurus were more associated with (Fig. 4b). A discrete segregation between juvenile and adult conspecifics from these species was observed, where $S$. adustus juveniles were strongly associated to the complex structure of fire-corals. This axis was, in the other hand, negatively represented by deeper patch reefs, contributing to high records of sandy bottoms, together with a high cover of live and dead massive corals. Such descriptors represented mostly Pete's reef and Conch Point samples (Fig. 4b). Axis I drove most of the juveniles of S. leucostictus, S. partitus, and S. variabilis abundance, as they were found associated with depth. Stegastes planifrons (juveniles and adults) showed a close relationship with massive and dead coral cover, together with adult S. partitus and S. leucostictus, showing preference for sparser patch reefs with higher cover of massive corals interspersed with sandy bottoms. Adult S. variabilis presented a distinct segregation from juveniles, but also associating with deeper patch reefs, explained by axis II.

\section{Discussion}

\section{Habitat use}

Although this work used a more quantitative approach than previous studies, damselfish distribution seemed to follow the prevailing patterns of habitat use found for this group of fishes throughout the Caribbean Sea in the last decades (Itzkowitz, 1977; Waldner \& Robertson, 1980; Robertson, 1981, 1984, 1996). However, differences were found in respect to benthic cover they associated to. In addition, it was possible to detect the habitat partitioning and segregation among different species.

At a broader scale, differences regarding reefs were found not only for damselfish species composition, but also for benthic communities. These differences may be due to the influence of wave energy. It has been demonstrated that wavestressed habitats are dominated by organisms with life histories adapted to a disturbance regime, presenting high resistance, such as coralline algal communities (Witman, 1992). In this study, reefs with more pronounced wave surge allowed a diverse algal community, including crutose types, as much as the encrusting and heavily calcified firecoral Millepora alcicornis, with a major 

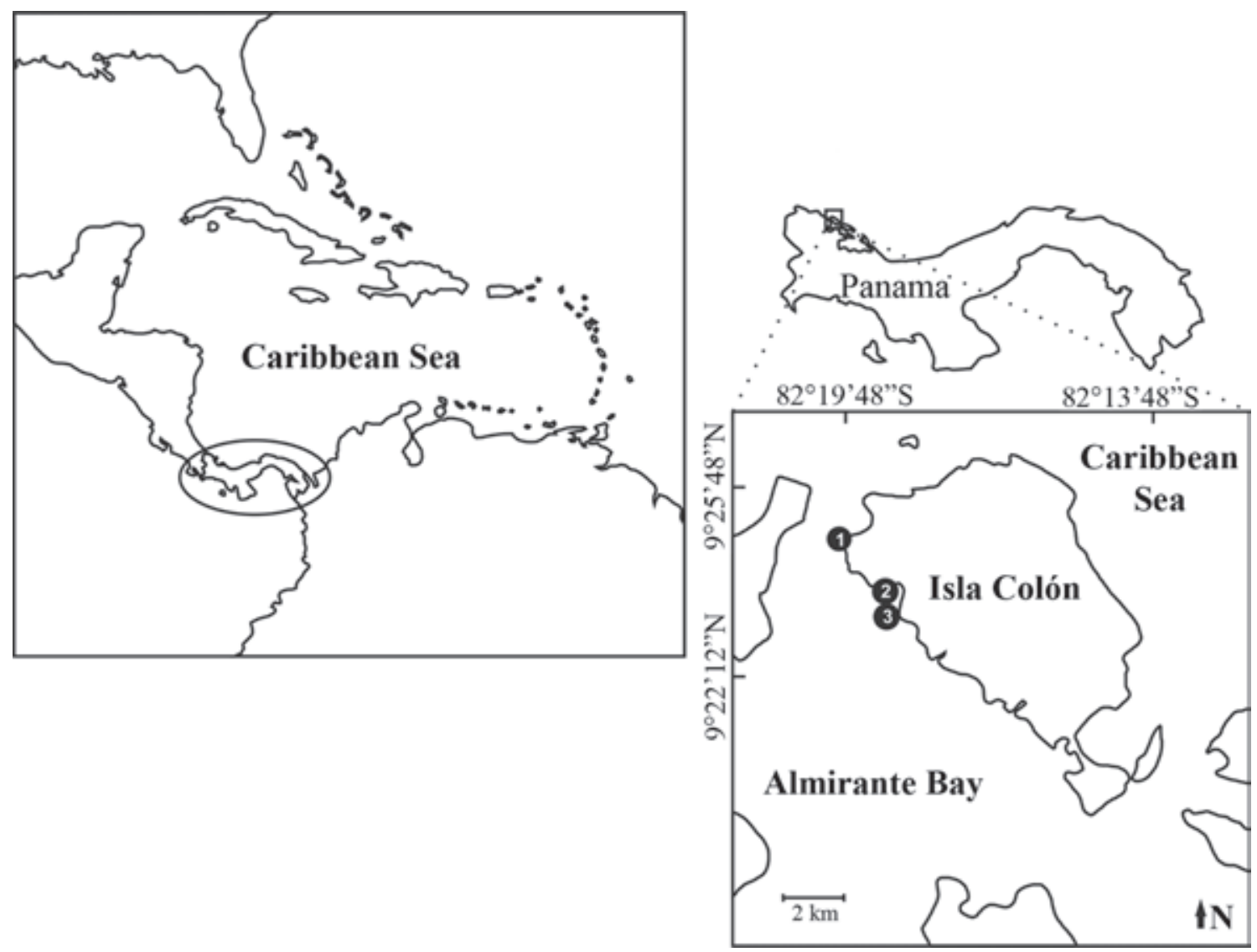

Fig. 1. Map of study area within the Caribbean region. 1-Lime Point; 2-Pete’s reef and; 3-Conch Point

contribution to bottom cover. In the other hand, sheltered reefs had a more prominent colonization of massive corals, such Montastraea spp. and Diploria spp.

Considering damselfish abundance, the dusky damselfish S. adustus presented higher abundances on Pete's reef and Lime Point, indicating a preference of this species for shallow habitats, but it exhibited a two-fold increase in abundance at higher wave surge. This species is not particularly abundant in other Panamanian reefs (Robertson, 1996), but has been already recognized to prefer shallow and high wave energy habitats (Waldner \& Robertson, 1980; Gutierrez, 1998; DominiciArosemena \& Wolff, 2005). It also refuges on structural complex colonies of the elkhorn coral Acropora cervicornis (Waldner \& Robertson, 1980). However, in this study, this species associated with colonies of the firecoral Millepora alcicornis, very resistant to water motion. As this hydrocoral presents a ramified hard structure, it apparently sustained the high abundance of $S$. adustus, as in many other reef fish species (Pereira et al., 2012; Coni et al., 2012). Moreover, wave exposure and any branching coral seem to be habitat requirements to the dusky damselfish, which should increase their vulnerability to habitat loss considering the massive mortality of Acroporid species throughout the Caribbean (Precht et al., 2002; 2010). Colonies of M. alcicornis seem to be also a preferred substrate for M. chrysurus, such as on Jamaica, Florida, Bahamas and
Panama (see Waldner \& Robertson, 1980; Robertson, 1984), and also on Brazilian tropical reefs (Ferreira et al., 2005). This study found that highest abundance of juvenile $M$. chrysurus followed this association and fish may use Millepora spp. not only for shelter, but perhaps also for feeding on the soft tissues, mucus or small epibionts (Ciardelli, 1967; Pereira et al., 2012).

In contrast, Stegastes planifrons was highly abundant in sheltered reefs, as previously noticed in other studies (Waldner \& Robertson, 1980; McGehee, 1994; DominiciArosemena \& Wolff, 2005). It was correlated especially with cover of live massive and dead corals, where its abundance increased. As past information on benthic cover is lacking one could not confirm pervasive habitat loss, however it is strong evidence that a habitat shift have occurred already for S. planifrons, as recently described by Precht et al., 2010. This author provided valuable information on the lethal consequences of habitat shifts of this species, from branching forms (Acropora spp.) to massive corals (Montastraea complex) and Porites porites, which are the main corals found in sheltered reefs of Isla Colón. Stegastes planifrons predation on living tissue and consequent extensive coral mortality, benefits the proliferation of algal gardens (Precht et al., 2010), and its association also with dead corals could be an indication of this activity by S. planifrons. Such relationship should be specifically addressed at this point. 
The role of interspecific interactions

Size and aggressiveness differences are among the most important factors driving the outcomes of competition for space in damselfish (Robertson \& Lassig, 1980; Robertson, 1984; Danilowicz, 1997). Damselfish of the genus Stegastes are relatively small territorial fish and some are considered extremely

ADULTS
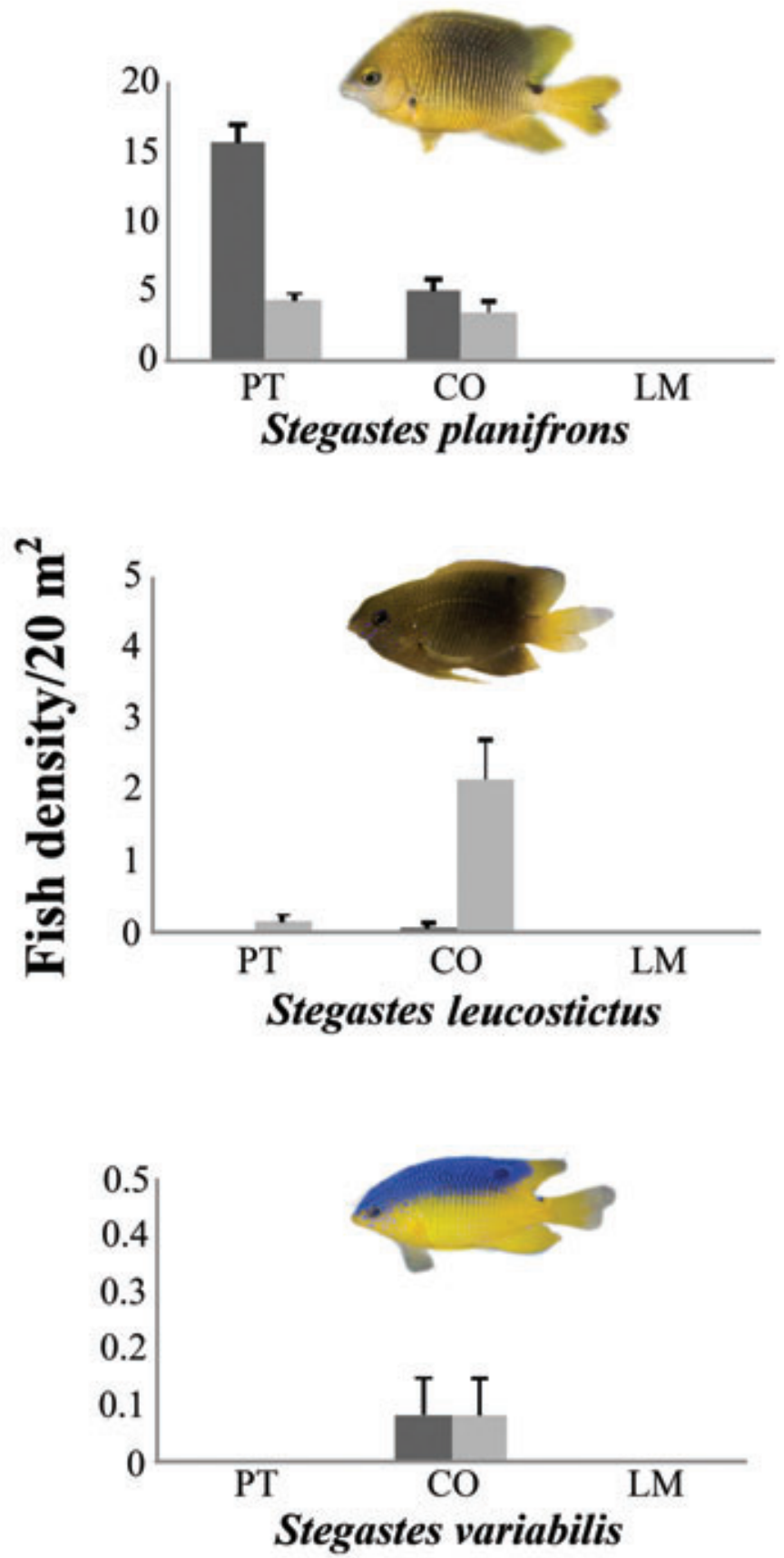

aggressive (Itzkowitz, 1977; Robertson, 1984; 1996; Menegatti et al., 2003; Osório et al., 2006; Medeiros et al., 2010). An invasion of territory usually results in aggressive responses towards both conspecifics and heterospecifics, including individuals two or three size bigger (Pereira \& Ferreira, 2012).

Adults of S. adustus and S. planifrons are more strongly

\section{JUVENILES}
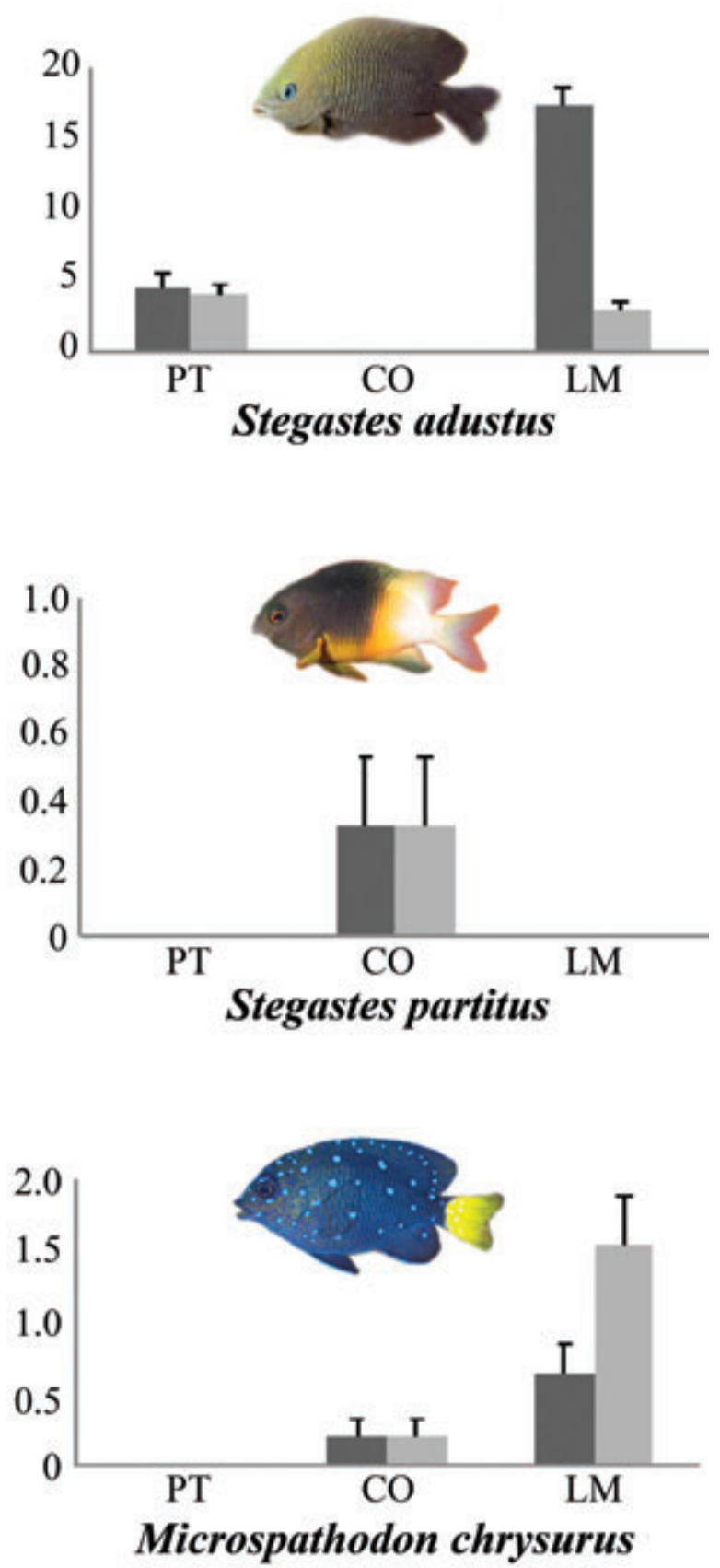

\section{Reefs}

Fig. 2. Mean density per $20 \mathrm{~m}^{2}$ ( \pm S.E) of damselfish species observed in Pete’s Reef (PT), Conch Point (CO) and Lime Point (LM). 
Resemblance: S17 Bray Curtis Similarity

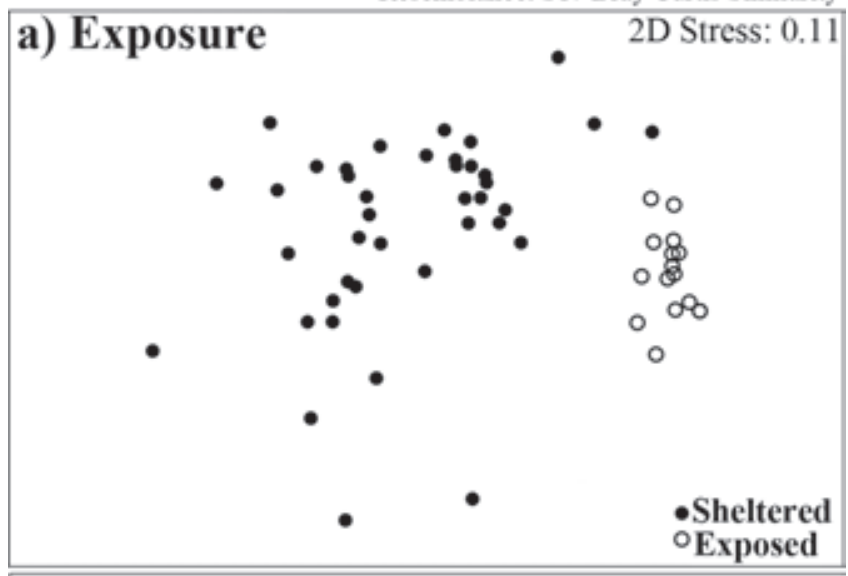

b) Depth

2D Stress: 0.11

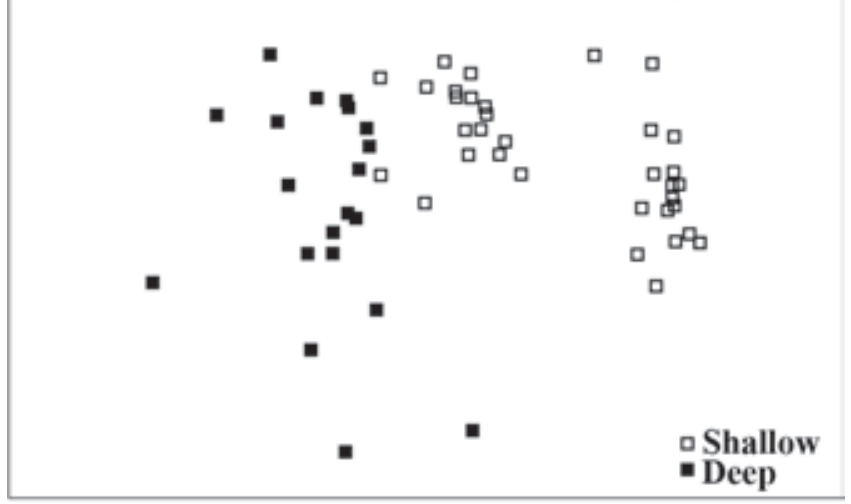

Fig. 3. MDS plots of damselfish community comparison between exposure and depth levels. dependent on benthic algae for food than S. partitus, which commonly feeds on both planktonic and benthic material, or S. leucostictus and S. variabilis, which are more omnivorous benthic feeders (Emery, 1973; Robertson, 1984), indicating that coinciding food resource use would only be compensated with less territory overlapping. Direct causal relationships between fish abundances are hard to detect and not always clearly evident, as they are highly dependable on the fluctuations in recruitment and adult populations. However, the effects of interspecific competition on demographics and distribution were already detected in damselfish (Robertson, 1996). Stegastes planifrons, by its aggressiveness and population numbers, is known to have a negative influence on S. partitus and S. variabilis abundance, assuming an asymmetric competitive relationship (Robertson, 1996).

Stegastes adustus is also abundant and aggressive (Robertson, 1996), but both species are known to show little overlap in their distribution (Waldner \& Robertson, 1980; Robertson, 1984; Gutiérrez, 1998). Herein they clearly followed the same trend in relation to adults of one another. The absence of S. planifrons on LM reefs and presence in lower abundance of $S$. adustus in PT indicate that the latter, at some level is a more habitat generalist in shallow depths, whereas $S$. planifrons seems to be more specialized, occurring generally only over live massive coral colonies, as described previously. These distributions indicate that interspecific competition could have strong effects on abundances of species in shared habitats of $S$. adustus and S. planifrons. However, habitat preferences would be the primary factor responsible for segregation, and that is observed since very early stages of life (Gutiérrez, 1998).

Furthermore, habitat partitioning by territorial herbivores
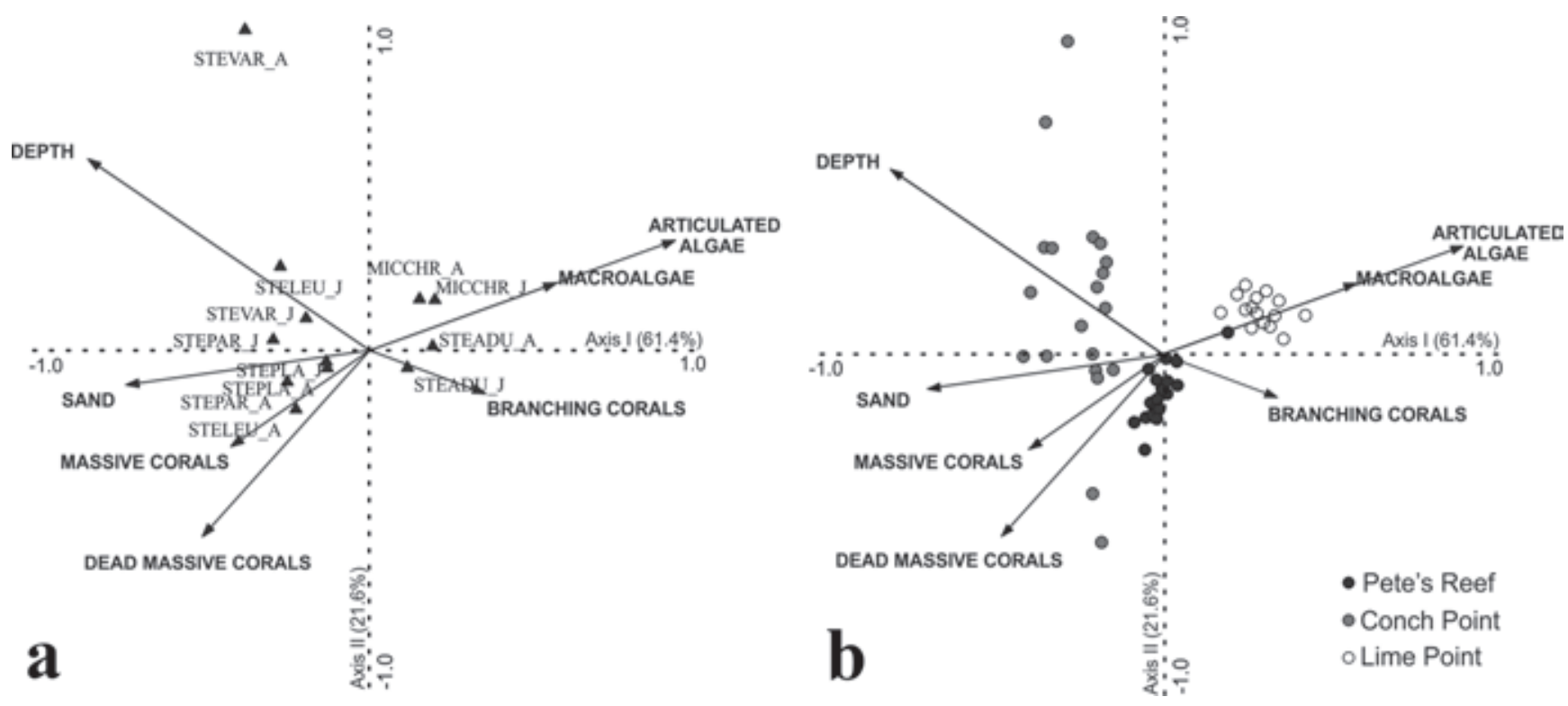

Fig. 4. Canonical correspondence analysis plot showing the correlations of the most significant variables (arrows) with fish species (a) and samples (b). Species codes: STEPLA = Stegastes planifrons; STEADU = Stegastes adustus; STELEU = Stegastes leucostictus; STEVAR = Stegastes variabilis; STEPAR = Stegastes partitus; MICCHR = Microspathodon chrysurus. The letters ( $\mathrm{J}$ and $\mathrm{A}$ ) following the species code names denote juvenile and adult, respectively. 
brings also light to other interactions than competition. Stegastes adustus and M. chrysurus reached higher abundances when sharing habitats at Lime Point reefs. In fact, this association was reported over three decades ago by other authors (Clarke, 1977; Itzkowitz, 1977; Waldner \& Robertson, 1980; Robertson, 1984), indicating an interesting pattern of behavior. The exclusion of $M$. chrysurus by adult S. planifrons is usually expected, due to the high aggression of the latter (Robertson, 1984). It has been argued that $M$. chrysurus may benefit from the smaller-sized S. adustus for its higher ability of territory defense, which may allow then to take long distance movements for reproduction ( Sikkel \& Kramer, 2006) or feeding activities.

Adults of $M$. chrysurus, although also associated with Millepora colonies on this study, are less dependent of shelter, attaining larger shared territories with S. adustus, and taking advantages of co-defense of their boundaries. Regardless of the fitness costs for the "host" Stegastes, this relationship indicates high stability of damselfish behavioral traits.

\section{Further considerations}

In spite of small-scale variability, similar trends were found for damselfish habitat use compared to previous studies. Although pre-recruitment processes are likely to play an important role, the high longevity of this group known to be over a decade long (Kohda, 1996; Schwamborn \& Ferreira, 2002), probably confers some population stability and contributes for the maintenance of their distributional patterns over a large time span. This stability, however, may be disrupted by major environmental changes such as the mass mortality of important structuring corals during disturbances (e. g. El-Niño events, hurricanes, diseases).

At a local spatial scale the presence of preferred habitats, such as live corals, is of major importance and a massive coral cover loss (almost 80\%) throughout the Caribbean in the last decades (Aronson \& Precht, 2001; Gardner et al., 2003; Guzman, 2003; Edmunds \& Elahi, 2007; Alvarez-Filip et al., 2009) may have resulted in lower recruitment and associated reduction in damselfish population size. For instance, $S$. planifrons faced decreased adult abundance after declines of Acropora spp. throughout Caribbean reefs, which represented negative consequences for secondary preferred habitats, such algae overgrowing massive corals (Precht et al., 2010).

Although the reefs studied are not yet considered algae dominated systems and past data are lacking, they have probably suffered modifications in the last decades due to natural and land based impacts. Bocas del Toro has been subjected to several anthropogenic disturbances due to the increasing tourism activity. This came together with other human impacts such as artisanal fisheries, sport fishing and the environmental stresses resulting from diving activities (Dominici-Arosemena \& Wolff, 2005). Yet, we have no knowledge on how damselfishes responded in a pervasive manner to these changes.
Damselfish patterns of local distribution may be good indicators of health on coral reef systems. As well adapted species to present conditions and in a scenario of community homogenization due to overfishing, hurricanes and other stressors along the Caribbean, the abundance patterns of $S$. planifrons and S. adustus in Isla Colón may be an important reference point. Moreover, understanding how these fish are facing changes and how good indicators they are would be a useful tool to become aware of such environment modifications.

\section{Acknowledgements}

We thank the staff and director of ITEC for providing facilities and local support. Special thanks to Team Ormondi: Micah Marty, Amy Fehr, Liat Krongrad, Adara Withers, Michelle Nagy, and Christian Paullin for field support. I am also in debt with João Lucas Feitosa and Ronaldo FranciniFilho for fruitful comments on this manuscript. Financial support for this work was provided by Conselho Nacional de Desenvolvimento Científico e Tecnológico (CNPq).

\section{Literature Cited}

Alvarez-Filip L., N. K. Dulvy, J. A. Gill, I. M. Côte' \& A. R. Watkinson. 2009. Flattening of Caribbean coral reefs: regionwide declines in architectural complexity. Proceedings of the Royal Society B, 276: 3019-3025.

Aronson, R. B. \& W. F. Precht. 2001. White-band disease and the changing face of Caribbean coral reefs. Hydrobiologia, 460: 25-38.

Bay, L. K., G. P. Jones \& M. I. McCormick. 2001. Habitat selection and aggression as determinants of spatial segregation among damselfish on a coral reef. Coral Reefs, 20: 289-300.

Ceccarelli, D. M., G. P. Jones \& L. S. McCook. 2001. Territorial damselfish as determinants of the structure of benthic communities on coral reefs. Oceanography and Marine Biology, 39: 355-389.

Ceccarelli, D. M., G. P. Jones \& L. J. McCook. 2005. Effects of territorial damselfish on an algal-dominated coastal coral reef. Coral Reefs, 24: 606-620.

Ceccarelli, D. M., G. P. Jones, L. J. McCook. 2011. Interactions between herbivorous fish guilds and their influence on algal succession on a coastal coral reef. Journal of Experimental Marine Biology and Ecology, 399:60-67.

Ciardelli A. 1967. The anatomy of the feeding mechanism and the food habits of Microspathodon chrysurus (Pisces: Pomacentridae). Bulletin of Marine Science, 17: 843-883.

Clarke, R. D. 1977. Habitat distribution and species diversity of chaetodontid and pomacentrid fishes near Bimini, Bahamas. Marine Biology, 40: 277-289.

Clarke, K. R. \& R. N. Gorley. 2001. PRIMER v5: user manual/ tutorial. PRIMER-E, Plymouth, U. K., 91p.

Coni, E. O. C., C. M. Ferreira, R. L. Moura, P. M. Meirelles, L. Kaufman \& R. B. Francini-Filho. (in press). An evaluation of the use of branching fire-corals (Millepora spp.) as refuge by reef fish in the Abrolhos Bank, eastern Brazil. Environmental Biology of Fishes.

Danilowicz, B. S. 1997. The effects of age and size on habitat selection during settlement of a damselfish. Environmental Biology of Fishes, 50: 257-265. 
Doherty, P. J. 1983. Tropical territorial damselfish: is recruitment limited by aggression or recruitment? Ecology, 64: 176-190.

Dominici-Arosemena, A. \& M. Wolff. 2005. Reef fish community structure in Bocas del Toro (Caribbean, Panamá) along spatial scales and gradients in habitat complexity. Caribbean Journal of Sciences, 41: 613-637.

Edmunds, P. J. \& R. Elahi. 2007. The demographics of a 15-year decline in coral cover of the Caribbean reef coral Montastaea annularis. Ecological Monographs, 77: 3-18.

Emery, A. R. 1973. Comparative ecology and functional osteology of fourteen species of damselfish (Pisces: Pomacentridae) at Alligator Reef, Florida Keys. Bulletin of Marine Science, 23: 649-770.

Ferreira, B. P., T. M. D’amico \& M. H. Reinhardt. 2005. Peixes ornamentais marinhos dos recifes de Tamandaré (PE): Padrões de distribuição, conservação e educação ambiental. Boletim Técnico-Científico do CEPENE, 13: 9-23.

Ferreira, C. E. L., J. E. A. Gonçalves, R. Coutinho \& A. C. Peret. 1998. Herbivory by the Dusky Damselfish Stegastes fuscus (Cuvier, 1830) in a tropical rocky shore: effects on the benthic community. Journal of Experimental Marine Biology and Ecology, 229: 241-264.

Gardner, T. A., I. M. Côte, J. A. Gill, A. Grant \& A. R. Watkinson. 2003. Long-term region-wide declines in Caribbean corals. Science, 301: 958-960.

Gleason, M. G. 1996. Coral recruitment in Moorea, French Polynesia: the importance of patch type and temporal variation. Journal of Experimental Marine Biology and Ecology, 207: 79101.

Gochfeld, D. J. 2010. Territorial damselfishes facilitate survival of corals by providing an associational defense against predators. Marine Ecology Progress Series, 398: 137-148.

Graham, N. A. J., S. K. Wilson, S. Jennings, N. V. C. Polunin, J. P. Bijoux, J. Robinson. 2006. Dynamic fragility of oceanic coral reef ecosystems. Proceedings of the National Academy of Sciences of the United States of America, 103: 8425-8429.

Guzmán, H. M. 2003. Caribbean coral reefs of Panama: present status and future perspectives. Pp. 241-274 In: Cortes, J. (Ed.). Latin American coral reefs. Amsterdam: Elsevier Science B.V.

Guzmán, H. M. \& C. A. Guevara. 1998a. Arrecifes coralinos de Bocas del Toro, Panamá: I. Distribución, estructura y estado de conservación de los arrecifes continentales de la laguna de Chiriquí y la Bahía Almirante. Revista de Biología Tropical, 46: 601-623.

Guzmán, H. M. \& C. A. Guevara. 1998b. Arrecifes coralinos de Bocas del Toro, Panamá: II. Distribución, estructura y estado de conservación de los arrecifes de las islas Bastimentos, Solarte, Carenero y Colón. Revista de Biología Tropical, 46: 893-916.

Guzmán, H. M. \& C. A. Guevara. 1999. Arrecifes coralinos de Bocas del Toro, Panamá: III. Distribución, estructura y estado de conservación de los arrecifes de las islãs Pastores, Cristóbal, Popa y Cayo Agua. Revista de Biología Tropical, 47: 659-675.

Guzmán, H. M. \& C. A. Guevara. 2001. Arrecifes coralinos de Bocas del Toro, Panamá: IV. Distribución, estructura y estado de conservación de los arrecifes continentales de Península Valiente. Revista de Biología Tropical, 49: 53-66.

Gutiérrez, L. 1998. Habitat selection by recruits establishes local patterns of adult distribution in two species of damselfishes: Stegastes dorsopunicans and S. planifrons. Oecologia, 115: 268277.

Hata, H. \& M. Kato. 2003. Demise of monocultural algal farms by exclusion of territorial damselfish. Marine Ecology Progress Series, 263: 159-167.
Hata, H. \& M. Kato. 2004. Monoculture and mixed-species algal farms on a coral reef are maintained through intensive and extensive management by damselfishes. Journal of Experimental Marine Biology and Ecology, 313: 285-296.

Hixon, M. A. \& J. P. Beets. 1993. Predation, prey refuges, and the structure of coral-reef fish assemblages. Ecological Monographs, 63: 77-101.

Hixon, M. A. \& W. N. Brostoff. 1983. Damselfish as keystone species in reverse intermediate disturbance and diversity of reef algae. Science, 220: 511-513.

Holbrook, S. J., G. E. Forrester \& R. J. Schmitt. 2000. Spatial patterns in abundance of a damselfish reflect availability of suitable habitat. Oecologia, 122: 109-120.

Hughes, T. P. 1994. Catastrophes, phase-shifts, and large-scale degradation of a Caribbean coral reef. Science, 265: 1547-1551.

Hughes, T. P., A. H. Baird, D. R. Bellwood, M. Card, S. R. Connolly, C. Folke, R. Grosberg, O. Hoegh-Guldberg, J. B. C. Jackson, J. Kleypas, J. M. Lough, P. Marshall, M. Nystrom, S. R. Palumbi, J. M. Pandolfi, B. Rosen \& J. Roughgarden. 2003. Climate change, human impacts and the resilience of coral reefs. Science, 301: 929-933.

Hughes, T. P., M. J. Rodrigues, D. R. Bellwood, D. M. Ceccarelli, O. Hoegh-Guldberg, L. McCook, N. Moltschaniwskyj, M. S. Pratchett, R.S. Steneck \& B. Willis. 2007. Phase shifts, herbivory, and the resilience of coral reefs to climate change. Current Biology, 17: 360-365.

Ilarri, M. I., A. T. Souza, P. R. Medeiros, R. G. Grempel \& I. M. L. Rosa. 2008. Effects of tourist visitation and supplementary feeding on fish assemblage composition on a tropical reef in the Southwestern Atlantic. Neotropical Ichthyology, 6: 651-656.

Itzkowitz, M. 1977. Spatial organization of the Jamaican damselfish community. Journal of Experimental Marine Biology and Ecology, 28: 217-241.

Jones, G. P., C. Syms. 1998. Disturbance, habitat structure and the ecology of fishes on coral reefs. Australian Journal Ecology, 23: 287-297.

Jones, G. P. \& M. I. McCormick, M. Srinivasan, J. V. Eagle. 2004. Coral decline threatens fish biodiversity in marine reserves. Proceedings of the National Academy of Sciences of the United States of America, 101: 8251-8253.

Jones, G. P., L. Santana, L. J. McCook \& M. I. McCormick. 2006. Resource use and impact of three herbivorous damselfishes on coral reef communities. Marine Ecology Progress Series, 328: 215-224.

Klumpp, D. W., A. D. McKinnon \& P. Daniel. 1987. Damselfish territories: zones of high productivity on coral reefs. Marine Ecology Progress Series, 40: 41-51.

Kohda, M. A. 1996. A damselfish living for more than 15 years: a longevity record for small reef fishes. Ichthyological Research, 43: 459-462.

Liddell, W. D., S. L. Ohlhorst \& S. K. Boss. 1984. Community patterns on the Jamaican fore reef (15-56 m). Palaeontographica Americana, 54: 385-389.

McClanahan, T. R., N. V. C. Polunin, T. J. Done. 2002. Resilience of coral reefs. Pp. 111-163. In: Gunderson, L. H., B. Jansson, C. S. Hollings \& C. Folke (Eds.). Resilience and the behavior of large-scale systems. Washington, DC Island Press.

McCook, L. J. 1999. Macroalgae, nutrients and phase shifts on coral reefs: Scientific issues and management consequences for the Great Barrier Reef. Coral Reefs 18: 357-367.

McGehee, A. 1994. Correspondence between assemblages of coral reef fishes and gradients of water motion depth, and substrate size off Puerto Rico. Marine Ecology Progress Series, 105: 243-255. 
Medeiros, P. R., R. G. Grempel, A. T. Souza, M. I. Ilarri \& C. L. S. Sampaio. 2007. Effects of recreational activities on the fish assemblage structure in a northeastern Brazilian reef. PanAmerican Journal of Aquatic Sciences, 2: 288-300.

Medeiros, P. R., A. T. Souza, M. I. Ilarri. 2010. Habitat use and behavioural ecology of the juveniles of two sympatric damselfishes (Actinopterygii: Pomacentridae) in the southwestern Atlantic Ocean. Journal of Fish Biology, 77: 1599-1615.

Meekan, M. G., A. D. L. Steven \& M. J. Fortin. 1995. Spatial patterns in the distribution of damselfishes on a fringing coral reef. Coral Reefs, 14: 151-161.

Menegatti, J. V., D. L. Vescovi \& S. R. Floeter. 2003. Interações agonísticas e forrageamento do peixe-donzela, Stegastes fuscus (Perciformes: Pomacentridae). Natureza On Line, 1: 45-50.

Osório, R., I. L. Rosa \& H. Cabral. 2006. Territorial defence by the Brazilian damsel Stegastes fuscus (Teleostei: Pomacentridae). Journal of Fish Biology, 69: 233-242.

Pandolfi, J. M., J. B. C. Jackson, N. Baron, R. H. Bradbury, H. M. Guzman,T. P. Hughes, C. V. Kappel, F. Micheli, J. C. Ogden, H. P. Possingham \& E. Sala. 2005. Are U.S. Coral Reefs on the Slippery Slope to Slime? Science, 307: 1725-1726.

Pereira, P. H. C. \& B. P. Ferreira. 2012. Agonistic behaviour of Haemulon spp. (Actinopterygii: Haemulidae) and other coral reef fishes in Northeastern Brazil. Cybium, 2012: 1-7.

Pereira, P. H. C., I. C. S. Leal, M. E. Araújo \& A. T. Souza. 2012. Feeding association between reef fishes and the fire coral Millepora spp. (Cnidaria: Hydrozoa). Marine Biodiversity Records, 5: e42.

Precht, W. F., R. B. Aronson, R. M. Moody \& L. Kaufman. 2010. Changing Patterns of Microhabitat Utilization by the Threespot Damselfish, Stegastes planifrons, on Caribbean Reefs. Plos One, 5: 1-8.

Precht, W. E, A. W. Bruckner, R. B. Aronson \& R. J. Bruckner. 2002. Endangered acroporid corals of the Caribbean. Coral Reefs, 21: 41-42

Robertson, D. R. 1984. Cohabitation of competing territorial damselfishes on a Caribbean coral reef. Ecology, 65: 1121-1135.

Robertson, D. R. 1996 Interspecific competition controls abundance and habitat use of territorial Caribbean damselfishes. Ecology, 77: 885-899.

Robertson, D. R., S. G. Hoffman, J. M. Sheldon. 1981. Availability of space for the territorial Caribbean damselfish Eupomacentrus planifrons. Ecology, 62: 1162-1169.
Robertson, D. R. \& B. Lassig. 1980. Spatial distribution patterns and coexistence of a group of territorial damselfishes from the Great Barrier Reef. Bulletin of Marine Sciences, 30: 187-203.

Scheffer, M., S. Carpenter, J. A. Foley, C. Folke, B. Walker. 2001. Catastrophic shifts in ecosystems. Nature, 413: 591-596.

Schwamborn, S. H. L. \& B. P. Ferreira. 2002. Age structure and growth of the dusky damselfish, Stegastes fuscus, from Tamandaré reefs, Pernambuco, Brazil. Environmental Biology of Fishes, 63: 79-88.

Spalding, M. D., C. Ravilious, E. P. Green. 2001. World Atlas of Coral Reefs. Berkeley, University of California Press, 424p.

Sikkel, P. C. \& D. L. Kramer. 2006. Territory revisits reduce intrusion during spawning trips by female yellowtail damselfish, Microspathodon Chrysurus. Animal Behavior, 71 :71-78.

Sweatman, H. P. A. 1985. The influence of adults of some coral reef fishes on larval recruitment. Ecological Monographs, 55: 469-485.

Szmant, A. M. 2001 Introduction to the special issue of Coral Reefs on "Coral reef algal community dynamics". Coral Reefs, 19: 299-302.

ter Braak, C. J. F. 1995. Ordination. In: Jongman, R. H. G., C. J. F. ter Braak \& O. F. R. Van Tongeren (Eds.). Data analysis in community and landscape ecology. Cambridge, Cambridge University Press, 212p.

Tolimieri, N. 1998. Contrasting effects of microhabitat use on largescale adult abundance in two families of Caribbean reef fishes. Marine Ecology Progress Series, 167: 227-239.

Waldner, R. E. \& D. R. Robertson. 1980. Patterns of habitat partitioning by eight species of territorial Caribbean damselfishes (Pisces: Pomacentridae). Bulletin of Marine Sciences, 30: 171-186.

Williams, D. McB. 1982. Patterns in the distribution of fish communities across the central Great Barrier Reef. Coral Reefs, 1: 35-43.

Wilson, D. \& M. G. Meekan. 2002. Growth-related advantages for survival to the point of replenishment in the coral reef fish Stegastes partitus (Pomacentridae). Marine Ecology Progress Series, 231: 247-260.

Witman, J. D. 1992. Physical disturbance and community structure of exposed and protected reefs: a case study. American Zoologist, 32: 641-654.

Submitted October 19, 2011

Accepted September 10, 2012 Published September 28, 2012 